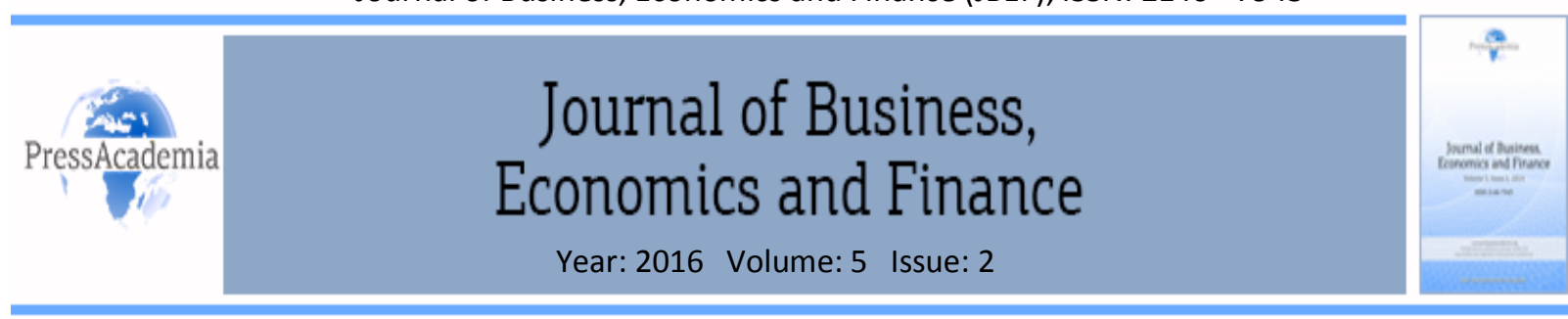

\title{
SUSTAINABILITY OF CURRENT ACCOUNT DEFICITS IN BRICS COUNTRIES
}

\section{DOI: 10.17261/Pressacademia.2016219259}

\author{
Serkan Tastan ${ }^{1}$, Kivanc Halil Aric ${ }^{2}$ \\ ${ }^{1}$ Cumhuriyet University. stastan@cumhuriyet.edu.tr \\ ${ }^{2}$ Cumhuriyet University. halilaric@gmail.com
}

\begin{abstract}
In this article, sustainability of the current account deficit (CAD) for BRICS countries is analyzed in a nonlinear framework. In this respect, Harvey, Leybourne, and Xiao (2008) linearity test and the unit root tests of Sollis (2009) and Kruse (2011) are used. The analysis is based on the quarterly current account (CA) balances as percentages of gross domestic product. Results indicate that the CADs are unsustainable for Brazil and India. However, the sustainability hypothesis is valid for South Africa when considering size nonlinearity.
\end{abstract}

Keywords: Current account, sustainability, BRICS, unit root, nonlinearity

JEL Classification: C22, F32, H62

\section{INTRODUCTION}

In this study, we analyzed the mean reverting process of CA for the BRICS countries Brazil, India and South Africa, respectively. These countries have survived the CAD. If the CA of the country is stationary then it can be said that the account is reverting. Conversely, if the CA of the country is not stationary in the long-run then the situation can lead to economic defaults such as bankruptcy and capital outflows (Christopoulos and Le'onLedesma 2010, 445). CA adjustment is relative to whether the process is linear or non-linear. In the linear context, CA adjustment is symmetric above and below the long-run equilibrium level. Also, adjustment speed is uncommitted to the extent of displacement from the long-run equilibrium level. Conversely, if the stationary stochastic process that manages the CA adjustment to its long-run equilibrium is nonlinear, then size and sign of the CA imbalance affect the adjustment process (Clarida, Goretti, and Taylor 2007, 172). The sign (asymmetric adjustment) effect implies that the CA responds in a different manner, depending on the sign of the shock; with the size (asymmetric speed of adjustment) effect the movement of the CA to its core equilibrium level depends upon the deviation from it. If the CAD is bigger than the threshold value, market participants and policy makers perceive this as an economic crisis signal (Chen and Xie 2015, 14; Chen 2014, 542).

We have two main goals to achieve for the BRICS countries. One goal is to ensure that the larger CA imbalances are different from the smaller current imbalances (size matter). The other is to have CADs differ from the CA surpluses (sign matter). First, we verified nonlinear behavior of time series by using Harvey, Leybourne, and Xiao (2008) linearity test and then examined the sign and size nonlinearities via the unit root tests of Sollis (2009) and Kruse (2011).

\section{LITERATURE REVIEW}

\subsection{Brazil}

The Brazilian economy displayed reliable economic conditions through raw material revenues and capital inflows, from 2003-2008. During this period, average annual growth was sustained at $+5 \%$ levels. However, this growth trend was supported primarily by consumption and fewer investments. The main economic problem 
was that domestic demand couldn't keep up with local production. Thus, inflation and CADs occured. To improve the business environment and competitiveness and solve the deficient investment situation, protectionism, excessive bureaucracy, high labor costs and tax system have to be regulated (Euler Hermes 2015). Blanchard (1983) investigates the Brazilian external debt problem as a major economic problem. He wanted to determine whether the CAD occured when consumption or investment spending reached high levels since CAs are formed by income and spending conditions. He concluded that if the growth rate of Brazil continues at high levels, consumption will not cause economic problems because debt can be paid in future periods. Also, he determined that if Brazil wants to reduce the CAD, this reduction will be attributed mainly to consumption rather than investment (Blanchard 1983, 187-196).

Regarding savings and investments, Brazil's private and public savings remained at low levels compared to other developing economies. Therefore, increasing domestic savings is imperative for improving external balances and rising investments. To improve savings, reforming the pension system and constraining public consumption should be implemented (International Monetary Fund 2015, 44-45). Donoso and Martin (2014, 749) examined the CA sustainability of Latin American countries. They used linear and nonlinear unit root tests and found that the CAs of Argentina, Brazil, Chile and Paraguay have not been sustainable. Raybaudi, Sola, and Spagnolo (2004) investigated Brazil's long run budget constraint (LRBC) conditions by using Markov's switching ADF model to determine periods when the CA accumulates in a non-stationary occasion. They concluded that Brazil temporarily encountered debt problems. This short-run imbalance can be attributed to future distortions of the LRBC.

\subsection{India}

The CA of India became unsustainable due to low productivity of government expenditures in 1990 and 1991. In this situation, borrowing costs are rising against the returns of investments (Parikh and Rao 2006, 494). After the balance of payments crisis in 1991, India implemented several reforms in the context of liberalizing the trade policy. The main purpose of these trade policy reforms are to expand the volume of trade, to import capital and technology easily, to increase foreign exchange reserves and finally, to maintain the balance of payments in a sustainable manner (Kubendran 2013). Since the 1950s the CAD of India has been at around 1$2 \%$ of the GDP in the long term. However, in the early 1990s, the deficit reached $3.2 \%$ of GDP and the CA became unsustainable. This was followed by India's currency crisis. In the 2001-2004 period, CA surpluses occurred, averaging $1.4 \%$ of GDP. Conversely, CADs occured from the period of 2008-2010. Deficit level averaged $2.5 \%$ of GDP (Singh 2015, 4935).

Parikh and Rao $(2006,503)$ analyzed the twin deficits problem of India by using cointegration and error correction methods. Their main finding was that reducing the domestic budget deficit can be used as a policy option to sustain India's balance of payments problems. Ramakrishna (2011) investigated the affects of India's trade policy on economic growth, balance of payments and CAD by using co-integration analysis. He concluded that trade liberalization policies positively impacted economic growth, balance of payments and CA balances. Nag and Mukherjee (2012) examined the long-term relationship between exports and imports of India by using unit root test and cointegration methods. They concluded that macroeconomic policies are not sufficient to sustain the trade deficit. Kubendran (2013) analyzed the CA sustainability of India. He found that the CAD became unsustainable because of the negative conditions in merchandise trade. If the government implements restrictions on import, the trade deficit and CAD can be more manageable. Suresh and Tiwari (2014) examined the twin deficits for the Indian economy by using Structural VAR analysis. They found that the fiscal deficit positively affected the CAD and twin deficit problems remained. Singh (2015) investigated the CA sustainability of India. He found that there is a long-term relationship between imports and exports in India. He asserts that rising export earnings and accumulative foreign exchange reserves are important for sustaining the CAD in the short run.

\subsection{South Africa}

Before 2003, there was not a process in place that was used to manage the CADs and surpluses in South Africa. Conversely, after 2003, the deficit grew in a stable phase and reached peak levels in 2008 at $7.4 \%$ of GDP (Kearney and Odusola 2011, 22). The CAD of South Africa averaged 5.5\% of GDP from 2012-2014. Net capital 
inflows accesses to the South Africa were increased from $\$ 2.7$ billion in 1993 to $\$ 50.7$ billion in 2012.This capital accumulation was used to enhance the foreign exchange reserves and to finance CADs (Smit, Grobler, and Nel 2014, 616).

Strauss (2015) asserts that foreign direct investment inflows can be upgraded to support the CAD. An equilibrium of balance of payments over the long run could be a result of foreign direct investments (Strauss $2015,13)$. Increasing savings rates and reducing consumption levels are important policy approaches for sustaining the CA in South Africa (Frankel and Sturzenegger 2008, 2). Searle and Mama (2010) investigated the sustainability of CADs in South Africa by using Engle and Granger ADF test in the period of 1994:1 to 2003:2. They concluded that the South African CAD is sustainable.

\section{DATA AND METHODOLOGY}

The quarterly CA balances of Brazil, India and South Africa as percentages of GDP have constituted the data set of this study. The data has been obtained from the website of the Organization for Economic Cooperation and Development (OECD). The sample periods, which vary based on available data, are 1996: 1-2014: 4 for Brazil, 2004: 2-2011: 2 for India and 1960: 1-2011: 1 for South Africa.

In this study, sustainability of the CA balance has been examined by using the approach of Trehan and Walsh (1991) and Hakkio and Rush (1991) for the intertemporal budget constraint. This approach implies that the CA balance can be sustainable if the long-term budget constraint is ensured by any important feedback on domestic savings and investments and any important variation on budget deficits. According to Trehan and Walsh (1991), the stationary CA is sufficient to provide the intertemporal budget constraint. International investors can be lent to an economy if they expect that the current value of the future stream of net exports surpluses equals the current stock of foreign debt. The present value of economy's net resource transfers to foreigners must equal the value of the economy's initial debt to them. A sufficient condition for that equality to hold is that the CA is stationary. When the growth rate of an economy is positive, CA sustainability can be ensured if the ratio $y_{t}=C_{t} / Y_{t}$ is stationary. This condition indicates that CA sustainability is possible with permanently CADs as long as they do not grow faster than output in terms of expected value. Thus, the sustainability hypothesis indicates that the debt to GDP ratio is constant in the long-run.

The linearity test proposed by Harvey, Leybourne, and Xiao (2008) is called the $\mathrm{W}_{\lambda}$ test. It can be applied when the order of integration of the time series under investigation is unknown. The proposed test is calculated with the following augmented test regressions:

$$
\begin{aligned}
& y_{\mathrm{t}}=\beta_{0}+\beta_{1} \mathrm{y}_{\mathrm{t}-1}+\beta_{2} \mathrm{y}_{\mathrm{t}-1}^{2}+\beta_{3} \mathrm{y}_{\mathrm{t}-1}^{3}+\sum_{\mathrm{j}=1}^{\mathrm{p}} \beta_{4, \mathrm{j}} \Delta \mathrm{y}_{\mathrm{t}-\mathrm{j}}+\epsilon_{\mathrm{t}} \\
& \Delta \mathrm{y}_{\mathrm{t}}=\lambda_{1} \Delta \mathrm{y}_{\mathrm{t}-1}+\lambda_{2}\left(\Delta \mathrm{y}_{\mathrm{t}-1}\right)^{2}+\lambda_{3}\left(\Delta \mathrm{y}_{\mathrm{t}-1}\right)^{3}+\sum_{\mathrm{j}=2}^{\mathrm{p}} \lambda_{4, \mathrm{j}} \Delta \mathrm{y}_{\mathrm{t}-\mathrm{j}}+\epsilon_{\mathrm{t}}
\end{aligned}
$$

For the case of I(0) and I(1) the null hypotheses of linearity are expressed respectively as $\mathrm{H}_{0,0}: \beta_{2}=\beta_{3}=0$ and $\mathrm{H}_{0,1}: \lambda_{2}=\lambda_{3}=0$. The standard Wald statistic for testing of $\mathrm{H}_{\mathrm{i}, 0}$ against the alternative of nonlinearity is:

$\mathrm{W}_{\mathrm{i}}=\mathrm{T}\left(\frac{\mathrm{RSS}_{\mathrm{i}}^{\mathrm{r}}}{\operatorname{RSS}_{\mathrm{i}}^{\mathrm{u}}}-1\right) \quad \mathrm{i}=0,1$

where $\mathrm{T}$ is sample size, $\mathrm{RSS}_{i}^{\mathrm{u}}$ and $\mathrm{RSS}_{\mathrm{i}}^{\mathrm{r}}$ are, respectively, the residual sums of squares from the unrestricted and restricted form of the Equation 1 for $i=0$ and Equation 2 for $i=1$. The $W_{\lambda}$ test statistic is calculated as a weighted average of $\mathrm{W}_{0}$ and $\mathrm{W}_{1}$ :

$$
\mathrm{W}_{\lambda}=(1-\lambda) \mathrm{W}_{0}+\lambda \mathrm{W}_{1}
$$

where $\lambda$ is a function defined from the standard Dickey-Fuller unit root statistic and the nonparametric stationary statistic of Harris, McCabe, and Leybourne (2003). $\mathrm{W}_{\lambda}$ follows an asymptotic $\mathrm{X}^{2}$ (2) distribution.

Sollis (2009) has extended the unit root test of Kapetanios, Shin, and Snell (2003) by using an asymmetric exponential smooth transition autoregressive (AESTAR) model that deals with both symmetry and asymmetry 
under the alternative hypothesis. The following auxiliary regression is used to test the null hypothesis of unit root against the alternative hypothesis of globally stationary symmetric or asymmetric ESTAR nonlinearity:

$\Delta \mathrm{y}_{\mathrm{t}}=\phi_{1} \mathrm{y}_{\mathrm{t}-1}^{3}+\phi_{2} \mathrm{y}_{\mathrm{t}-1}^{4}+\sum_{\mathrm{i}=1}^{\mathrm{k}} \delta_{\mathrm{i}} \Delta \mathrm{y}_{\mathrm{t}-\mathrm{i}}+\eta_{\mathrm{t}}$

If the null hypothesis of unit root $\left(\mathrm{H}_{0}: \phi_{1}=\phi_{2}=0\right)$ is rejected then $\mathrm{H}_{0}: \phi_{2}=0$ should be tested to determine the type of ESTAR nonlinearity (i.e. symmetric or asymmetric).

Another extension for the unit root test of Kapetanios, Shin, and Snell (2003), which allows for a nonzero location parameter in the exponential transition function, is proposed by Kruse (2011). The author uses the modified Wald test statistic $(\tau)$ of Abadir and Distaso (2007) to test $\mathrm{H}_{0}: \delta_{1}=\delta_{2}=0$ against $\mathrm{H}_{1}: \delta_{1}<0, \delta_{2} \neq 0$ in the following auxiliary regression:

$\Delta \mathrm{y}_{\mathrm{t}}=\delta_{1} \mathrm{y}_{\mathrm{t}-1}^{3}+\delta_{2} \mathrm{y}_{\mathrm{t}-1}^{2}+\sum_{\mathrm{i}=1}^{\mathrm{k}} \rho_{\mathrm{i}} \Delta \mathrm{y}_{\mathrm{t}-\mathrm{i}}+\eta_{\mathrm{t}}$

Using the $\tau$ test statistic the null hypothesis of unit root is tested against globally stationary ESTAR. Both Sollis' and Kruse's unit root tests can be applied to raw data, demeaned or detrended data.

\section{FINDINGS AND DISCUSSIONS}

We have applied the linearity test of Harvey, Leybourne, and Xiao (2008) to test for the presence of nonlinearity in the time series. According to the $W_{\lambda}$ test statistics, the null hypothesis of linearity is rejected for Brazil and India at a significance level of $5 \%$ and at $1 \%$ for South Africa. Since all the series are nonlinear, the stationary of the CA can be examined in a nonlinear framework that considers different adjustment processes based on the size and sign of the CA imbalance. The ESTAR type unit root test of Kruse (2011) is used to test size nonlinearity alone, whereas the AESTAR unit root test of Sollis (2009) allows for the testing of sign and size nonlinearities simultaneously. We have applied the AESTAR and Kruse (2011) unit root tests to the raw, demeaned and detrended data. Unit root test results are reported along with the linearity test results in Table 1. As seen in Table 1, we cannot reject the null hypothesis of unit root even at the $10 \%$ significance level for Brazil and India except for the detrended data of India. On the other hand, the null hypothesis is rejected at the $1 \%$ significance level for South Africa according to both unit root tests. As pointed out in Cuestas $(2013,236)$, since the CA to GDP ratio is analyzed against convergence to an equilibrium value, the demeaned data should be focused. Therefore, we have concluded that only the CA to GDP ratio of South Africa is stationary and sustainable among analyzed countries. Furthermore, the CA to GDP ratio of South Africa exhibits symmetric ESTAR nonlinearity, namely that the adjustment towards equilibrium is symmetric.

Table 1: The $\mathrm{W}_{\lambda}$ Linearity, AESTAR and $\tau$ Unit Root Tests Results

\begin{tabular}{cccccc}
\hline & & $W_{\lambda}$ & $\phi_{1}=\phi_{2}=0$ & $\phi_{2}=0$ & $\tau$ \\
\hline \multirow{3}{*}{ Brazil } & Raw data & & 0.61 & - & 4.12 \\
& Demeaned & $7.98^{* *}$ & 1.18 & - & 2.56 \\
& Detrended & & 0.85 & - & 1.89 \\
\hline \multirow{2}{*}{ India } & Raw data & & 0.09 & - & 3.46 \\
& Demeaned & \multirow{2}{*}{$8.15^{* *}$} & 1.59 & - & 5.68 \\
& Detrended & & $5.93^{*}$ & $4.38^{* *}$ & $35.59^{* * *}$ \\
\hline \multirow{2}{*}{ South } & Raw data & & $16.70^{* * *}$ & $5.11^{* *}$ & $32.46^{* * *}$ \\
Africa & Demeaned & $12.03^{* * *}$ & $16.49^{* * *}$ & 0.45 & $32.55^{* * *}$ \\
& Detrended & & $16.93^{* * *}$ & 1.22 & $33.08^{* * *}$ \\
\hline
\end{tabular}

Note: ${ }^{*},{ }^{* *}$ and ${ }^{* * *}$ denote rejection at the $10 \%, 5 \%$ and $1 \%$ significance levels, respectively. 


\section{CONCLUSION}

The results of our study indicate that the CAD is not sustainable in Brazil and India. For Brazil; unsustainable conditions can be explained by insufficient savings and investments conditions, deficient business environment and competitiveness, unrelated circumstances between domestic demand and local production. If political regulations are implemented to improve these economic conditions, sustainability of the CA for Brazil can be maintained. Unsustainable conditions for India can be defined to include a high domestic budget deficit, insufficient macroeconomic policies and negative conditions in merchandise trade. If the government wants to reduce the CAD in India, some economic policies can be implemented such as reducing budget deficits and regulations on imports to improve merchandise trade conditions. On the other hand, the CAD is sustainable for South Africa. It can be said that the main factor of the CAD sustainability is a result of capital inflows to South Africa. Our results support the notion that only size matters for the South African CAD sustainability. This implies that the mean reverting process does not depend on the sign of CA. The speed of mean reverting of the CA deficit or surpluses to the equilibrium level is related with the size of the CA deficit or surpluses. Our results for these countries are consistent with those of Donoso and Martin (2014), Raybaudi, Sola, and Spagnolo (2004) which of them find unsustainable CAD for Brazil. Kubendran (2013) result that unsustainable CAD for India. Searle and Mama (2010) results that sustainable CA for South Africa.

\section{REFERENCES}

Abadir, K. M. \& Distaso, W. 2007, "Testing Joint Hypotheses When One of the Alternatives Is One-Sided", Journal of Econometrics, vol. 140, no. 2, pp. 695-718.

Blanchard, O. J. 1983, "Debt and the Current Account Deficit in Brazil”, NBER Working Series. Accessed 8 September 2015. http://www.nber.org/chapters/c11192.pdf.

Chen, S. W. \& Xie, Z. 2015, "Testing for Current Account Sustainability under Assumptions of Smooth Break and Nonlinearity", International Review of Economics \& Finance, vol. 38, pp. 142-156. doi:10.1016/j.iref.2015.02.015.

Chen, S. W. 2014, "Smooth Transition, Non-Linearity and Current Account Sustainability: Evidence from the European Countries", Economic Modelling, vol. 38, pp. 541-554. doi:10.1016/j.econmod.2014.02.003.

Christopoulos, D. \& Le'on-Ledesma, M. G. 2010, "Current Account Sustainability in the US: What Did We Really Know About It?", Journal of International Money and Finance, vol. 29, no. 3, pp. 442-459. doi:10.1016/j.jimonfin.2009.06.014.

Clarida, R. H., Goretti, M. \& Taylor, M. P. 2007, "Are There Thresholds of Current Account Adjustment in the G7", NBER Working Paper Series. Accessed 22 November 2015. http://www.nber.org/chapters/c0120

Cuestas, J. C. 2013, "The Current Account Sustainability of European Transition Economies", Journal of Common Market Studies, vol. 51, no. 2, pp. 232-245. doi:10.1111/j.1468-5965.2012.02309.x.

Donoso, V. \& Martin, V. 2014, "Current Account Sustainability in Latin America", The Journal of International Trade \& Economic Development, vol. 23, no. 5, pp. 735-753. doi:10.1080/09638199.2013.775322.

Euler Hermes. 2015, “Country Report Brazil 2015 Worst Recession Since 1990”, Euler Hermes Economic Research. Accessed 12 November 2015. http://www.eulerhermes.com/economic-research/country-reports/Pages/Brazil.aspx

Frankel, J. \& Sturzenegger, F. 2008, "Policy Brief-South Africa's Macroeconomy”, Center for International Development at Harvard University, May. Accessed 16 November 2015. http://www.cid.harvard.edu/southafrica/docs/cid_policybrief_macro.pdf

Hakkio, C. S., \& Rush, M. 1991, “Is The Budget Deficit Too Large?”, Economic Inquiry, vol. 29, no. 3, pp. 429-445. doi:10.1111/j.14657295.1991.tb00837.x.

Harris, D., McCabe, B. \& Leybourne, S. 2003, "Some Limit Theory For Autocovariances Whose Order Depends On Sample Size", Econometric Theory, no. 10, pp. 829-864. doi:10.1017/s0266466603195060.

Harvey, D. I., Leybourne, S. J. \& Xiao, B. 2008, "A Powerful Test for Linearity When the Order of Integration Is Unknown", Studies in Nonlinear Dynamics \& Econometrics, vol. 12, no. 3. doi:10.2202/1558-3708.1582.

International Monetary Fund. 2015, "Brazil", IMF Country Report No.15/12, May. Accessed 27 November 2015. http://www.imf.org/external/pubs/ft/scr/2015/cr15121.pdf

Kapetanios, G., Shin, Y. \& Snell, A. 2003, "Testing for a Unit Root in the Nonlinear STAR Framework", Journal of Econometrics, vol. 112, no. 2, pp. 359-379. doi:10.1016/s0304-4076(02)00202-6. 
Kearney, M. \& Odusola, A. 2011, "Assessing Development Strategiest to Achieve the MDGs in the Republic of South Africa”, United Nations Department for Social and Economic Affairs, March. Accessed 27 Nowember 2015.http://www.un.org/en/development/desa/policy/capacity/output_studies/roa87_study_zaf.pdf

Kruse, R. 2011, “A New Unit Root Test Against ESTAR Based on a Class of Modified Statistics”, Statistical Papers, vol. 52, no. 1, pp. 71-85. doi:10.1007/s00362-009-0204-1.

Kubendran, N. 2013, "Sustainability of Persisting Current Account Deficits in India", Journal of International Economics, vol. 4, no. 2, pp. 7289.

Directorate-General for External Policies, April. Accessed 23 November http://www.ab.gov.tr/files/ardb/evt/1_avrupa_birligi/1_9_politikalar/1_9_8_dis_politika/The_role_of_BRICS_in_the_developing_world.pd

Nag, B. \& Mukherjee, J. 2012, "The Sustainability of Trade Deficits in the Presence of Endogenous Structural Breaks: Evidence from the Indian Economy", Journal of Asian Economics, vol. 23, no. 5, pp. 519-526. doi:10.1016/j.asieco.2012.05.003.

Parikh, A. \& Rao, B. 2006, “Do Fiscal Deficits Influence Current Accounts? A Case Study of India”, Review of Development Economics, vol. 10, no. 3, pp. 492-505. doi:10.1111/j.1467-9361.2006.00370.x.

Ramakrishna, G. 2011, "India's Trade Policy: The Impact on Economic Growth, Balance of Payments and Current Account Deficit”, Journal of International Economics, vol. 2, no. 1, pp. 4-17.

Raybaudi, M., Sola, M. \& Spagnolo, F. 2004, "Red Signals: Current Account Deficits and Sustainability", Economics Letters, vol. 84, no. 2, pp. 217-223. doi:10.1016/j.econlet.2004.02.005.

Searle, P. \& Mama, A. T. 2010, "The Sustainability of South African Current Account Deficits", University of Cape Town Working Paper 188. September. Accessed 19 November 2015. http://www.econrsa.org/papers/w_papers/wp188.pdf

Singh, T. 2015, "Sustainability of Current Account Deficits in India: An Intertemporal Perspective", Applied Economics, vol. 47, no. 46, pp. 4394-4951. doi:10.1080/00036846.2015.1039701.

Smit, B., Grobler, C. \& Nel, C. 2014, "Sudden Stops and Current Account Reversals: Potential Macroeconomic Consequences for South Africa", South African Journal of Economics, vol. 82, no. 4, pp. 616-627. doi:10.1111/saje.12069.

Sollis, R. 2009, "A Simple Unit Root Test Against Asymmetric STAR Nonlinearity with an Application to Real Exchange Rates in Nordic Countries", Economic Modelling, vol. 26, no. 1, pp. 118-125. doi:10.1016/j.econmod.2008.06.002.

Strauss, I. 2015, "Understanding South Africa's Current Account Deficit: The Role of Foreign Direct Investment Income", Africa Economic Brief, vol. 6, no. 4, pp. 1-14.

Suresh, K. G. \& Tiwari, A. K. 2014, "A Structural VAR (SVAR) Analysis of Fiscal Shocks on Current Accounts in India", Macroeconomics and Finance in Emerging Market Economies, vol. 7, no. 1, pp. 140-153. doi:10.1080/17520843.2013.828764.

Trehan, B. \& Walsh, C. E. 1991, "Testing Intertemporal Budget Constraints: Theory and Applications to US Federal Budget Deficits and Current Account Deficits", Journal of Money, Credit and Banking, vol. 26, no. 2, pp. 206-223. 